\title{
The Effect of Training and Compensation on Organizational Commitment with Job Satisfaction as Moderating Variable at PT. Bank Central Asia Tbk. Malang Branching
}

\author{
Rina Rahmawati ${ }^{1}$, Tommy Ariane Suyanto ${ }^{2 *}$ \\ ${ }^{1}$ STIE Malangkucecwara Malang, East Java, Indonesia, \\ ${ }^{* 2}$ Students of Postgraduate STIE Malangkucecwara Malang, East Java, Indonesia
}

\begin{abstract}
Human resources are one of the key aspects of a company's success and to realize company goals, companies are required to be able to improve the performance of their employees because of the role of human resources (HR). Therefore, the researcher aims to determine the effect of job training on organizational commitment, the effect of job compensation on organizational commitment, the effect of job training on organizational commitment with job satisfaction as a moderating variable, the effect of job compensation on organizational commitment with job satisfaction as a moderating variable, and the effect of job satisfaction. Work on organizational commitment at PT Bank Central Asia Malang Branch. The type of research carried out is explanatory research and with a quantitative approach. The results of the research that the training variable has a positive and significant effect on the satisfaction variable, the compensation variable has a positive and significant effect on the satisfaction variable, the training variable has a positive and significant effect on the satisfaction variable mediated by commitment, the compensation variable has a positive and significant effect on the satisfaction variable mediated by commitment, satisfaction has a positive and significant effect on the commitment variable, and commitment can be a mediating variable for the effect of training on satisfaction.
\end{abstract}

Keywords: Training, Compensation, Commitment, Satisfaction.

\section{Introduction}

Human resources are one of the key aspects of a company's success in facing the competition in the business world. To realize the goals set by the company, the company is required to be able to improve the performance of its employees because the role of human resources (HR) has a very large influence on the success of a business.

BCA (2021) Information on the BCA website is for optimal production, PT. Bank Central Asia, Tbk implements a system that is able to work in synergy and dynamically. This system involves efficient human resources, technology that keeps up with the times, and 
company policies that can support the interaction between human resources and technology.

\section{Literature Review}

\section{Work Training}

Stephen (2017) "Using training and development to affect job satisfaction within franchising" (the effect of implementing training and development on job satisfaction for franchise company employees) research results prove that the quality of training and development has a significant effect on job satisfaction.

L. Mathis (2015) argues that job training is a process by which people acquire capabilities to help achieve organizational goals.

\section{Compensation}

Research Boles et al. (2007) in several American companies stated that appropriate salary and promotion will affect the employee's desire to remain loyal to the organization.

\section{Job satisfaction}

Hsiao (2012) in his research conducted on several companies in Taiwan stated that job satisfaction has a significant positive effect on organizational commitment. From the explanation of the research above, job satisfaction helps in the employee training process which will have a good impact on organizational commitment and will advance the company well.

According to Kurcgant (2012) there are several indicators in job satisfaction as described, namely (1) Intensive care nurses are services provided to patients in critical, lifethreatening conditions, so they must be carried out by trained and experienced teams in intensive care rooms. Critical nursing services aim to provide care for patients with serious illnesses that require intensive therapy and have the potential to be cured; (2) Considering a number of work components (remuneration, professional status) is a reward for services rendered to employees not based on seniority or number of hours worked but adjusted to competence, and given fairly according to the basic needs of employees; (3) Autonomy is the degree of freedom, independence, and discretion that a person has in planning a job and determining what method is used to carry out the work; (4) Organization policies are written rules which are formal organizational decisions that have a binding nature on members associated with the organization, which can regulate behavior with the aim of creating new values in society; (5) Work requisites are requirements that must be met by a person in order to be accepted as an employee or employee; (6) Interaction with the nursenurse and nurse-physican subdividions are interactions that occur between nurses and patients, nurses and nurses, and nurses with other health professionals when providing nursing services to patients. These relationships include professional communication, 
nursing documentation systems, duty operations, start and end conferences, team work and leadership skills.

Organizational Commitment

Research conducted by Adeyinka Tella (2017). Work Motivation, Job Satisfaction, and Organizational Commitment of Library Personnel in Academic and Research Libraries in Oyo State, Nigeria. The findings of this study indicate that there is a correlation between motivation, job satisfaction, and commitment, although the relationship between motivation and commitment is negative.

\section{Research Methods}

The type of research conducted is explanatory research. The approach in this research is a quantitative approach. The types of data used are secondary data and primary data. In this study, the population used is all employees at PT Bank Central Asia Tbk. Borobudur Malang branch which includes: KCP Lawang, KCP Singosari, KCP Blimbing, and KCP Tumpang. The number of samples in this study were 110 employees at PT Bank Central Asia Tbk. Borobudur Branch Malang City. The sampling technique in this study used a purposive sample. The criteria for the sample in this study were permanent employees of PT Bank Central Asia Tbk. Borobudur branch, employees who have or have attended training from PT Bank Central Asia Tbk and employees who have received compensation in the form of salaries, allowances, etc. The variables in this study include; The independent variables are X1 (Job Training), X2 (Compensation), the moderating variable $\mathrm{Z}$ (Job Satisfaction) and the dependent variable Y1 (Organizational Commitment).

Path Chart

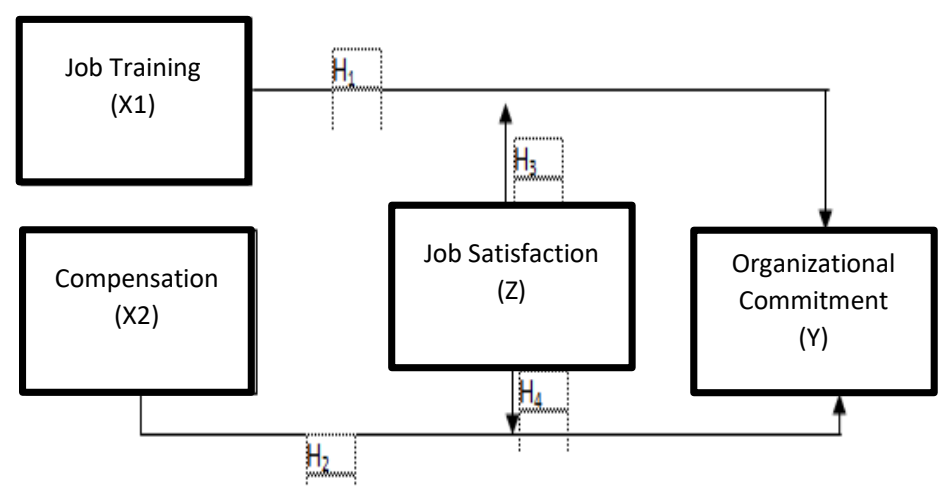

Figure 3.1 Path Diagram

\section{Research Result}

The results of the variable validity test on the training variable, compensation variable, satisfaction variable and commitment variable are as follows:

Table 4.1: Training Variable Validity Test Results 


\begin{tabular}{|l|ll|l|l|l|}
\hline Item-Total Statistics & & \\
\hline & $\begin{array}{l}\text { Scale Mean if } \\
\text { Item Deleted }\end{array}$ & $\begin{array}{l}\text { Scale Variance } \\
\text { Item Deleted }\end{array}$ & if & $\begin{array}{l}\text { Corrected Item-Total } \\
\text { Correlation }\end{array}$ & $\begin{array}{l}\text { Cronbach's Alpha if } \\
\text { Item Deleted }\end{array}$ \\
\hline X1.1 & 14.8667 & 5.982 & .804 & .845 \\
X1.2 & 14.9333 & 5.720 & .689 & .857 \\
X1.3 & 14.5333 & 4.602 & .760 & .845 \\
X1.4 & 14.9667 & 5.551 & .676 & .859 \\
X1.5 & 14.5667 & 5.151 & .715 & .851 \\
\hline
\end{tabular}

Based on the output of the validity test of the research instrument on the Training variable, it was found that as many as 5 statements in the questionnaire were valid because all Corrected Item-Total Correlation ( $\mathrm{r}$-count) values were greater than $\mathrm{r}$-table $(0.1562)$ so that all items were declared valid.

Table 4.2: Compensation Variable Validity Test Results

Item-Total Statistics

\begin{tabular}{|l|ll|l|l|l|}
\hline & $\begin{array}{l}\text { Scale Mean if } \\
\text { Item Deleted }\end{array}$ & $\begin{array}{l}\text { Scale Variance if } \\
\text { Item Deleted }\end{array}$ & $\begin{array}{l}\text { Corrected Item- } \\
\text { Total Correlation }\end{array}$ & $\begin{array}{l}\text { Cronbach's Alpha if Item } \\
\text { Deleted }\end{array}$ \\
\hline X2.1 & 8.2000 & 1.683 & .584 & .634 \\
X2.2 & 7.9000 & 1.128 & .581 & .652 \\
X2.3 & 7.9667 & 1.620 & .553 & .653 \\
\hline
\end{tabular}

Based on the output of the validity test of the research instrument on the Compensation variable, it was found that as many as 3 statements in the questionnaire were valid because all Corrected Item-Total Correlation (r-count) values were greater than $r$-table $(0.1562)$ so that all items were declared valid.

Table 4.3: Satisfaction Variable Validity Test Results

\begin{tabular}{|l|l|l|l|l|}
\hline \multicolumn{5}{|l|}{ Item-Total Statistics } \\
\hline
\end{tabular}


Based on the output of the validity test of the research instrument on the Satisfaction variable, it was found that as many as 6 statements in the questionnaire were valid because all Corrected Item-Total Correlation (r-count) values were greater than $r$ table $(0.1562)$ so that all items were declared valid.

Table 4.4: Commitment Variable Validity Test Results

\begin{tabular}{|c|c|c|c|c|}
\hline \multicolumn{5}{|c|}{ Item-Total Statistics } \\
\hline & $\begin{array}{l}\text { Scale Mean if } \\
\text { Item Deleted }\end{array}$ & $\begin{array}{l}\text { Scale Variance if } \\
\text { Item Deleted }\end{array}$ & $\begin{array}{l}\text { Corrected Item- } \\
\text { Total } \\
\text { Correlation }\end{array}$ & $\begin{array}{l}\text { Cronbach's Alpha if } \\
\text { Item Deleted }\end{array}$ \\
\hline Y1.1 & 7.6667 & 1.816 & .657 & .630 \\
\hline Y1.2 & 7.6667 & 1.816 & .575 & .706 \\
\hline Y1.3 & 7.8000 & 1.476 & .582 & .720 \\
\hline
\end{tabular}

Based on the output of the validity test of the research instrument on the Commitment variable, it was found that as many as 3 statements in the questionnaire were valid because all Corrected Item-Total Correlation (r-count) values were greater than r-table $(0.1562)$ so that all items were declared valid.

The results of the path analysis path test used to see the influence between variables, which are as follows:

Table 4.5: the Results of the Path Coefficient of Training Variables (X1), and Compensation (X2) Test Results on Satisfaction (Z)

\begin{tabular}{|l|l|l|l|}
\hline Variabel & Beta & t-count & P-Value \\
\hline Training_X1 & 0.417 & 4.835 & 0.000 \\
\hline Compensation_X2 & 0.596 & 7.270 & 0.000 \\
\cline { 1 - 2 } r2=0.601 & Critical Value t-table $=0.1857$ & \\
\cline { 1 - 1 } KD $=60.1 \%$ & \multicolumn{2}{|l}{} \\
\cline { 1 - 1 }
\end{tabular}

\section{Training (X1)}

Based on the results of the statistical calculation of the effect of Training (X1), on Satisfaction $(Z)$ shows the t-count of the Training variable (X1) of 4.835, the P-Value value of 0.000 and the coefficient (beta) of 0.417 . The results of the t-test illustrate that the $\mathrm{t}$ count is greater than the t-table $(4,835>0.1857)$. Based on the P-Value, the calculation results show that the P-Value is less than significant (0.000). These results can be explained that the t-count value is greater than the t-table and the P-Value value is smaller than the significant value. The path coefficient value (beta) has a positive number, then the result is significant and positive.

\section{Compensation (X2)}


Based on the results of the statistical calculation of the effect of Compensation (X2), on Satisfaction $(Z)$ shows the t-count of the Compensation variable (X2) of 7.270, the P-Value value of 0.000 and the coefficient (beta) of 0.596 . The results of the t-test illustrate that the $\mathrm{t}$-count is greater than the t-table $(7.270>1.9828)$. Based on the P-Value, the calculation results show that the $\mathrm{P}-\mathrm{Value}$ is greater than significant $(0.000)$. These results can be explained that the t-count value is greater than the t-table and the P-Value value is smaller than the significant value. The path coefficient value (beta) has a positive number, then the result is significant and positive. In the results of testing the effect of the variable Training (X1), and Compensation (X2) on Satisfaction (Z) has an r2 of 0.601 or a coefficient of determination (KD) of $60.1 \%$. These results explain that the results of testing the effect of Training (X1), and Compensation (X2) contributed $60.1 \%$ influence on the Satisfaction variable $(\mathrm{Z})$.

Table 4.6: Path Coefficient Test Results of Training Variables (X1) and Compensation (X2) Against Satisfaction (Z) Mediated by Commitment (Y2).

\begin{tabular}{|l|l|l|l|}
\hline Variabel & Beta & t-count & P-Value \\
\hline Training_X1 & 0.110 & 2.490 & 0.014 \\
\hline Compensation_X2 & 0.140 & 3.013 & 0.003 \\
\hline Satisfaction_Z & 0.218 & 4.886 & 0.000 \\
\hline r2=0.636 & Critical Value t-table $=0.1857$ & \\
\hline KD $=63.6 \%$ & & \\
\hline
\end{tabular}

\section{Training (X1)}

Based on the results of the statistical calculation of the effect of training (X1), on satisfaction (Z) mediated by commitment (Y2), the t-count of the training variable (X1) is 2,490 , the P-Value value is 0.014 and the coefficient (beta) is 0.110 . The results of the t-test illustrate that the $\mathrm{t}$-count is greater than the t-table $(2,490>0.1857)$. Based on the P-Value, the calculation results show that the P-Value is smaller than significant (0.014). These results can be explained that the t-count value is greater than the t-table and the P-Value value is smaller than the significant value. The path coefficient value (beta) has a positive number, then the result is significant and positive.

\section{Compensation (X2)}

Based on the results of the statistical calculation of the effect of compensation (X2), on satisfaction (Z) mediated by commitment (Y2), the t-count of the compensation variable (X2) is 3.013, the P-Value value is 0.003 and the coefficient (beta) is 0.140 . The results of the t-test illustrate that the t-count is greater than the t-table $(3.013>0.1857)$. Based on the $\mathrm{P}$-Value, the calculation results show that the $\mathrm{P}-\mathrm{V}$ alue is less than significant (0.003). These results can be explained that the $\mathrm{t}$-count value is greater than the $\mathrm{t}$-table and the P-Value 
value is smaller than the significant value. The path coefficient value (beta) has a positive number, then the result is significant and positive.

\section{Satisfaction (Z)}

Based on the results of the statistical calculation of the effect of Satisfaction $(\mathrm{Z})$ on Commitment (Y2), it shows that the t-count of the Satisfaction variable (Z) is 4.886 , the PValue is 0.000 and the coefficient (beta) is 0.218 . The results of the t-test illustrate that the $\mathrm{t}$-count is greater than the t-table (4.886>0.1857). Based on the P-Value, the calculation results show that the P-Value is less than significant (0.000). These results can be explained that the $\mathrm{t}$-count value is greater than the t-table and the P-Value value is smaller than the significant value. The path coefficient value (beta) has a positive number, then the result is significant and positive. In the results of testing the effect of the variable Training (X1) and Compensation (X2) on Satisfaction (Z) mediated by Commitment (Y2), it has an r2 of 0.636 or a coefficient of determination $(\mathrm{KD})$ of $63.6 \%$. These results explain that the results of testing the influence of the variables Training (X1) and Compensation (X2) mediated by Commitment (Y2) $63.6 \%$ on the variable Satisfaction (Z).

Results Based on the Sobel test, it shows that the statistical Sobel value is 4.03110 or greater than the ttable value $(4.03110>2.45)$ or it can be seen that there is a positive and significant effect of Training (X1) on the Commitment Variable (Y2) moderated by goal (Z). So it can be said that $(\mathrm{Z})$ can be a mediating variable for the effect of Training (X1) on Commitment (Y2).

Based on the results of the Sobel test, it shows that the Sobel statistic value is 4.03110 or greater than the t table value $(4.03110>2.45)$ or it can be seen that there is a positive and significant effect of Compensation (X2) on the Commitment Variable (Y2) moderated by Satisfaction (Z). So it can be concluded that satisfaction $(\mathrm{Z})$ can be a mediating variable for the effect of compensation (X2) on commitment (Y2).

\section{Conclusion}

Based on the results of research and discussion in the previous chapter, the research will conclude from the results of the study, namely the Training Variable (X1) has a positive and significant effect on the Satisfaction variable $(\mathrm{Z})$, so that hypothesis 1 (H1) can be said to be accepted; The Compensation Variable (X2) has a positive and significant effect on the Satisfaction variable $(\mathrm{Z})$, so that hypothesis $2(\mathrm{H} 2)$ can be said to be accepted; The Training Variable (X1) has a positive and significant effect on the Satisfaction variable (Z) mediated by Commitment (Y2), so that hypothesis 3 (H3) can be said to be accepted; Compensation variable (X2) has a positive and significant effect on the Satisfaction variable ( $\mathrm{Z}$ ) which is mediated by Commitment (Y2), so that hypothesis 4 (H4) can be said to be accepted; Satisfaction (Z) has a positive and significant effect on the Commitment variable (Y2), so that hypothesis 5 (H5) can be said to be accepted; and Commitment (Y2) can be a mediating variable for the effect of Training (X1) on Satisfaction (Z). 


\section{References}

1) Adeyinka, Tella. (2017). Work Motivation, Job Satisfaction, and Organisational Commitment of Library Personnel in Academic and Research Libraries in Oyo State. Library Philosophy and Practice 2017.

2) Bank Central Asia (BCA). (2021). Tentang Bank Central Asia (BCA). https://www.bca.co.id/tentang-bca

3) Boles, J. Madupalli R, Rutherford, B dan Wood J.a. (2007). The relationship of facet of salesperson job satisfaction with affective organizational commitment. Journal of Business and Industrial Marketing, Vol 22, No. 5 pp. 311-321

4) Hsiao, J.M. dan Chen Y.C. (2012). Antecedents and Consequences of Job Ssatisfaction: A Case of Automobile Component Manufacturer in Taiwan. Journal of Organizational Innovation, 5 (2), pp: 164-178.

5) L. Mathis, Robert \& H. Jackson, John. (2011). Human Resource Management (edisi 10). Jakarta : Salemba Empat.

6) Siqueira, V. T. A., \& Kurcgant, P. (2012). Satisfação no trabalho: indicador de qualidade no gerenciamento de recursos humanos em enfermagem. Revista da Escola de Enfermagem da USP, 46(1), 151-157.

7) Stephen Choo, Christine Bowley. (2017). Using training and development to affect job satisfaction within franchising. Journal of Small Business and Enterprise Development Vol. 14 No. 2, 2017.

\section{Works Cited}

Rina Rahmawati, Tommy Ariane Suyanto. (2021). The Effect of Training and Compensation on Organizational Commitment with Job Satisfaction as Moderating Variable at PT. Bank Central Asia Tbk. Malang Branching. International Journal of Scientific and Management Research, 04(04), 71-78. doi:http://doi.org/10.37502/IJSMR.2021.4406 